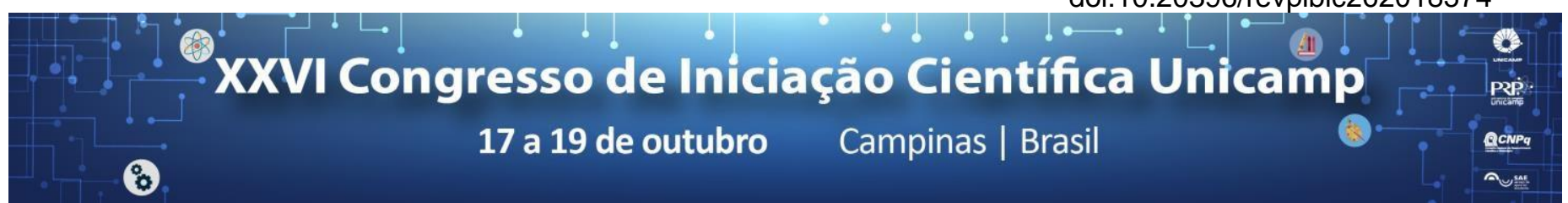

Eduardo Marcomini ${ }^{\star}$, Felipe do Rocio Brizola,Ingrid Alves Ramos,Luciana C. B. Botelho, Ana Paula Machado, Mariani Strapazzon dos Santos, Elisangela de Paula Rodrigues, Kamile Maria das G. Salgado, Desiré Luciane Dominschek.

\title{
Resumo
}

\section{A formação política a partir da iniciação científica e da iniciação a docência.}

Esta pesquisa tem como objetivo descrever o trabalho efetivado pelos bolsistas pibidianos durante o momento em que as escolas públicas do estado do Paraná passaram por longos dias de greve. Como a atividade de iniciação à docência precisou ser interrompida visto a greve, os pibidianos foram orientados a pesquisar os fatos e acontecimentos ocorridos e que culminaram no enfrentamento de um movimento de greve árduo pelos professores da rede estadual de ensino. $\mathrm{O}$ objetivo desta pesquisa foi a formação política de nossos futuros professores e também o resgate histórico dos acontecimentos que permearam o movimento de greve. Neste foco o trabalho tem como tema norteador a greve dos professores do Estado do Paraná que aconteceu em 2015 este estudo tem a finalidade de apresentar de maneira cronológica as fases da greve, e as negociações com o governo do Estado. Realizamos esta pesquisa com base no Jornal da APP-Sindicato de Março deste ano e as notícias da greve publicadas na internet pelo Jornal Gazeta do Povo desde a data 04 a 25 de fevereiro de 2015. Optamos por pesquisa documental e pesquisa de campo, e além da pesquisa documental trabalhamos também com entrevistas com professores e alunos. A pesquisa motivou a busca pela compreensão de como iniciou e porque, o movimento de greve dos professores, verificar a cronologia dos principais fatos que marcaram o embate entre professores e governo do Paraná nos traz a perspectiva de análise do contexto histórico daquele momento, e ainda como estratégias para entender este contexto pudemos realizar entrevistas com professores e alunos. Com base nas discussões realizadas nas reuniões de formação do Pibid, e também nas pesquisas realizadas sobre o movimento, problematizamos o movimento de greve dos professores como espaço de pesquisa, de formação e ação política. Neste sentido, concordamos com Saviani (2014) que o conhecimento ocupa lugar importante no capitalismo porque é parte das forças produtivas, mas o seu desenvolvimento, no entanto, entra em conflito com as relações de produção. Desse modo, a luta no ambiente escolar pressupõe direcionamentos para o socialismo, e lutar pela socialização do saber bem como para a socialização dos bens produzidos é lutar pelo social.

\section{Palavras-chave:}

greve,formação política,iniciação a docência.

\section{Introdução}

Esse ano foi muito marcante na vida dos professores da rede estadual do Paraná, eles se obrigaram a abandonar as sala de aula e ir as ruas, acampar em praça pública, mas como verdadeiros educadores também lá ensinaram. Durante o primeiro semestre deste ano as escolas estaduais do Paraná passaram por momentos preocupantes, foram feitos cortes, das verbas destinadas a manutenção dos prédios, foram fechadas turmas e trabalhadores escolares PSSs não foram contratados, estes foram os motivos que levaram os professores a decidirem pela paralisação que se iniciou no dia 9 de fevereiro, uma "greve de resistência" como nos explica a Pedagoga Jaqueline, "Não lutamos por melhores salários ou mais benefícios, lutamos para manter tudo que conquistamos ao longo dos anos, que estão sendo tirados aos poucos" (2015), ou seja muitos avanços a educação paranaense conquistou desde 1988 , e para continuar progredindo foi necessário resistir até as últimas consequências. $\mathrm{O}$ primeiro

acordo entre professores e governo aconteceu no dia 9 de março.

\section{Resultados e Discussão}

O movimento de greve dos professores da rede estadual de educação do Paraná foi um dos fatos mais marcantes do ano de 2015 para a sociedade paranaense. Essa luta foi considerada pela maioria dos profissionais de educação como uma luta de resistência, para evitar o desmanche das escolas, para manter os programas do mais educação, garantir a manutenção do Paraná Previdência e o pagamento dos professores contratados em regime especial, selecionados pelo PSS Processo Seletivo Simplificado.

\section{Conclusões}

Durante todo a pesquisa notou-se nitidamente a preocupação dos professores com seus alunos, desde o início quando lutavam contra o desmanche das escolas, até o fim com a preocupação com o termino do ano letivo. Como aponta Saviani "em política o objetivo é vencer e não convencer. Inversamente, em educação o objetivo é convencer e não vencer." (2012,

p. 82). Isso ficou muito claro durante todo período da paralisação, pois a sociedade foi convencida pelos professores através de fortes argumentos que a resistência aos atos do governo era necessária, ao contrário o governo que na ânsia de vencer tomou a decisão absurda do uso da força.

\footnotetext{
KLENK, L. A. 1988-2015: Os saldos da violência nas manifestações de professores no Paraná. Revista educação. São Paulo, n.218, p. 28 a 30, 2015. Disponível em: <http://revistaeducacao.uol.com.br/textos/218/1988-2015-saldosda-violencia-354436-1.asp > Acesso em: 14 jul. 2015

SAVIANI, D. Formação de professores: Aspectos históricos e teóricos do problema no contexto brasileiro. Revista Brasileira e de educação, v. 14, nº 40, p. 153. jan./abr. 2009. Disponível em: < http://www.scielo.br/pdf/rbedu/v14n40/v14n40a12.pdf> Acesso em : 20 mar. 2015
} 